\title{
Properties of a Gonococcal Inhibitor Produced by Escherichia coli
}

\author{
By DIANE M. SIMPSON AND CHARLES P. DAVIS \\ The University of Texas Medical Branch, Department of Microbiology, \\ Galveston, Texas 77550, U.S.A.
}

(Received 30 April 1979)

\begin{abstract}
Strains of Escherichia coli can inhibit the in vitro growth of Neisseria gonorrhoeae. One $E$. coli strain released a potent agar-diffusible gonococcal growth inhibitor which was extracted and assayed in an agar well assay system. The culture conditions necessary to produce the inhibitor were determined. The inhibitor was bacteriostatic, in most cases, for $N$. gonorrhoeae. Based on ultrafiltration and column chromatography, the inhibitor appeared to have a molecular weight in the range of 1200 to 2000. Evidence that the molecule contained charged sites was obtained by membrane binding and column chromatography. The inhibitor was stable to extremes of heat, cold and $\mathrm{pH}$. It was not volatile or susceptible to proteolytic enzymes, lysozyme, lipase, DNAase, RNAase or certain chelating agents. Its activity was completely blocked by ferric ammonium citrate. This inhibitor is dissimilar to previously reported gonococcal inhibitors of bacterial origin.
\end{abstract}

\section{INTRODUCTION}

As demonstrated by Geizer (1968) and Kraus et al. (1976), certain strains of Escherichia coli inhibit the in vitro growth of Neisseria gonorrhoeae. Several factors affect the production of the inhibitor, including the strain of $E$. coli and the size and duration of the gonococcal challenge (Kraus et al., 1976). In these studies, however, no attempt was made either to show the in vitro inhibition of $N$. gonorrhoeae with a cell-free extract or to isolate the inhibitor.

The present work confirms and extends the findings of Kraus et al. (1976). Differences between two strains of $E$. coli that produced a gonococcal inhibitor were observed. This report describes the effect of variations in the agar medium used to cultivate $E$. coli on the production of the inhibitor and shows that the inhibitor functions in a cell-free assay system. In addition, initial studies on the extraction and chemical characterization of this gonococcal growth inhibitor are described.

\section{METHODS}

Media. GCI agar was GC Medium Base (Difco) or GC Agar Base (BBL) supplemented with IsoVitaleX $(B B L)$ at $1 \%(\mathrm{v} / \mathrm{v})$. This medium was used in $20 \mathrm{ml}$ amounts for the plate assay of the gonococcal inhibitor and for some experiments on the production of the gonococcal inhibitor by a ' $\mathrm{D}$ ' type strain of $E$. coli (Kraus et al., 1976). Exceptions to this are noted in the text. GCI broth contained ( $\left.\mathrm{g} \mathrm{l}^{-1}\right)$ : polypeptone peptone (BBL), $15 ; \mathrm{KH}_{2} \mathrm{PO}_{4}, 1 ; \mathrm{K}_{2} \mathrm{HPO}_{4}, 4 ; \mathrm{NaCl}, 5$; and either corn starch (CPC International, Englewood Cliffs, N.J., U.S.A.) or soluble starch (Difco), 1 ; after autoclaving, sterile IsoVitaleX to give $1 \%(\mathrm{v} / \mathrm{v})$ was added. Laboratory-prepared (Lab) GCI agar and semi-solid Lab GCI agar were prepared from GCI broth by the addition of Bacto-agar (Difco) at 10 and $4 \mathrm{~g} \mathrm{l}^{-1}$, respectively. Minimal Medium(MM) broth contained $\left(\mathrm{g} \mathrm{l}^{-1}\right): \mathrm{K}_{2} \mathrm{HPO}_{4}, 7 ; \mathrm{KH}_{2} \mathrm{PO}_{4}, 3$; trisodium citrate. $2 \mathrm{H}_{2} \mathrm{O}, 0.5 ; \mathrm{MgSO}_{4} .7 \mathrm{H}_{2} \mathrm{O}, 0 \cdot 1 ;\left(\mathrm{NH}_{4}\right)_{2} \mathrm{SO}_{4}, 1$; and glucose, 2. Double-distilled deionized water was used in all media.

Organisms. Two strains of $E$. coli, derived from clinical specimens, were studied. One, designated $E$. coli 'D', was a strong growth inhibitor of $N$. gonorrhoeae F62 and the other, designated $E$. coli 'B', was a weak inhibitor. Seven strains of $N$. gonorrhoeae [WP and F62 (donated by Ann James, Department of Micro- 
biology, Baylor College of Medicine, Houston, Tex., U.S.A.), Catlins auxotype 1 - ATCC E27628 (1) which requires fewest added nutrients, and four fresh clinical isolates, one of which produced $\beta$-lactamase (all donated by Anne Goulde, Houston Health Department, Houston, Tex., U.S.A.)] were examined for their sensitivity to the inhibitor. In addition, the four colonial types of N. gonorrhoeae F62 were examined for their response to the inhibitor.

Preliminary assay of the gonococcal inhibitor in situ. The amount of gonococcal inhibitor released by the two clinical isolates of $E$. coli grown on GCI agar was monitored for $5 \mathrm{~d}$ as follows. A $5 \mu \mathrm{l}$ inoculum from a stock suspension of each $E$. coli strain containing approx. $5 \times 10^{7}$ colony-forming units (c.f.u.) $\mathrm{ml}^{-1}$ was dropped on to a sterile filter paper disc $(6.5 \mathrm{~mm}$ diam.) which was then placed centrally on a $20 \mathrm{ml} \mathrm{GCl}$ agar plate. Sufficient cultures of each strain were prepared to allow both serial and some replicate assays to be made over the course of $5 \mathrm{~d}$ incubation at $37^{\circ} \mathrm{C}$. After each period of incubation, the growth of $E$. coli was removed with cotton swabs and the plates were exposed to chloroform vapour to kill any remaining bacteria. After allowing the residual chloroform vapour to evaporate ( $30 \mathrm{~min}$ in a ventilated hood), a standard inoculum (approx. $4 \times 10^{5}$ c.f.u. per plate) of $N$. gonorrhoeae F62 colony type 4 in $20 \%$ (v/v) glycerol GCI broth was spread over each plate which was then incubated in a candle jar at $37^{\circ} \mathrm{C}$ for 18 to $24 \mathrm{~h}$. The width of the zone of inhibition was measured as the distance from the edge of the area of $E$. coli growth to the edge of confluent gonococcal growth.

Inhibition of $N$. gonorrhoeae by E. coli ' $D$ '. The response of the strains of $N$. gonorrhoeae to the gonococcal inhibitor produced by $E$. coli 'D' was examined by the technique of Kekessy \& Piquet (1970).

Nutrient resupplementation. Kraus et al. (1976) showed that the inhibition of normal in vitro gonococcal growth could still occur after $E$. coli cells had been removed from the surface of a solid medium when this was resupplied with essential nutrients. Therefore, before testing the inhibitory activity of the site of $E$. coli growth for $N$. gonorrhoeae F62, Catlins auxotype 1 and a fresh clinical isolate, $0.2 \mathrm{ml}$ IsoVitaleX was added to $0.2 \mathrm{ml}$ distilled water containing $3 \%(\mathrm{w} / \mathrm{v})$ polypeptone peptone and $0.2 \mathrm{ml}$ of this solution was flooded over each plate and allowed to soak in for approx. $2 \mathrm{~h}$ (Kraus et al., 1976).

Extraction of gonococcal inhibitor from E. coli ' $D$ ' cultures. One $\mathrm{ml}$ of either a freshly thawed stock suspension or a freshly prepared suspension of $E$. coli ' $\mathrm{D}$ ', both in $20 \%(\mathrm{v} / \mathrm{v})$ glycerol GCI broth, containing approx. $5 \times 10^{2}$ c.f.u. $\mathrm{ml}^{-1}$ was spread over each $20 \mathrm{ml} \mathrm{GCI}$ agar plate. After incubation at $37^{\circ} \mathrm{C}$ for $5 \mathrm{~d}$ the growth was removed with cotton swabs and the plates were exposed to chloroform vapour followed by ventilation as described above. The agar was then removed with sterile forceps and placed in sterile centrifuge tubes. The agar in these tubes was minced for 10 to $30 \mathrm{~s}$, suspended in the tube by a vortex mixer and then centrifuged at $1800 \mathrm{~g}$ for $20 \mathrm{~min}$. Following centrifugation, the supernatant liquid was decanted off. Control supernatant liquid was prepared from GCI agar plates spread with glycerol GCI broth without $E$. coli ' $D$ '.

Activity in broth of gonococcal inhibitor extracted from $E$. coli ' $D$ ' plate cultures. One $\mathrm{ml}$ of either $E$. coli ' $\mathrm{D}$ ' or control plate supernatant liquid was mixed with $2 \mathrm{ml} \mathrm{GCI}$ broth, the $\mathrm{pH}$ was adjusted to 7.2 to 8.0 (in individual experiments within $\pm 0.2 \mathrm{pH}$ units) and the resultant mixture was tested for sterility by incubation at $37^{\circ} \mathrm{C}$ for 18 to $24 \mathrm{~h}$. A $1 \mathrm{ml}$ inoculum prepared from a frozen stock suspension and containing approx. 500 c.f.u. $N$. gonorrhoeae $\mathrm{F} 62$ colony type 4 was then added to $1 \mathrm{ml}$ amounts of the supernatant fluid/GCI broth mixture. Three samples were withdrawn after $10 \mathrm{~min}$ and plated on GCI agar. The plates and the supernatant fluid/GCI broth cultures were then incubated in candle jars at $37^{\circ} \mathrm{C}$. After 4 and $8 \mathrm{~h}$, the plating procedure was repeated in triplicate. After 18 to $24 \mathrm{~h}$ incubation, the c.f.u. on each plate were counted.

Plate assay of gonococcal inhibitor extracted from $E$. coli ' $D$ ' plate cultures. Wells $(6.5 \mathrm{~mm}$ diam) cut in GCI agar plates were filled with $50 \mu \mathrm{l}$ of the assay material. The plates were incubated for $2 \mathrm{~h}$ at $37^{\circ} \mathrm{C}$ to allow the liquid to diffuse from the wells, and then an inoculum of approx. $2.5 \times 10^{3}$ c.f.u. N. gonorrhoeae F62 colony type 4, from a frozen stock suspension contained in $0.1 \mathrm{ml} 20 \%(\mathrm{v} / \mathrm{v})$ glycerol GCI broth, was spread evenly with a glass rod over the surface of the plate. The plates were incubated at $37^{\circ} \mathrm{C}$ in a candle jar for 18 to $25 \mathrm{~h}$ after which the widths of the zones of inhibition were measured from the edge of the well to the area of normal gonococcal colony growth. Zones were also graded with reference to the quality of the inhibition as follows: $3+$ represented a clear zone around the well bordered by a narrower zone of small colonies; $2+$, a clear zone around the well bordered by a larger zone of small colonies; $1+$, a zone of small colonies around the well; 0 , no inhibition evident.

Influence of medium composition on production of gonococcal inhibitor by $E$. coli ' $D$ '. Petri dishes containing $20 \mathrm{ml}$ of the following media were each flooded with $1 \mathrm{ml}$ of a suspension in $20 \%(\mathrm{v} / \mathrm{v})$ glycerol GCI broth of $E$. coli ' $\mathrm{D}$ ' containing approx. $5 \times 10^{7}$ c.f.u. $\mathrm{ml}^{-1}$ and then incubated at $37^{\circ} \mathrm{C}$ for $5 \mathrm{~d}$ (media i to viii) or $11 \mathrm{~d}$ (media ix to xi). (i) GCI agar made from either GC Agar Base (BBL) or GC Medium Base (Difco, Lot No. 637166 or 634368) or Lab GCI agar; (ii) Lab GCI agar from which either polypeptone peptone, $\mathrm{NaCl}$, starch or IsoVitaleX was omitted; (iii) an agar containing only polypeptone peptone and Bacto-agar in the same concentration as in Lab GCI agar; (iv) an agar containing only polypeptone peptone and purified agar (Difco, Lot No. 0560-01-1) in the same concentration as in Lab GCI agar; (v) an agar containing only 
Bacto-peptone (Difco) and purified agar in the same concentration as in Lab GCI agar; (vi) Lab GCI agar in which the amount of polypeptone peptone was either $5,10,15,20,25$ or $30 \mathrm{gl}^{-1}$; (vii) $\mathrm{Lab} \mathrm{GCI}$ agar in which Bacto-peptone was substituted for polypeptone peptone; (viii) Lab GCI agar containing $5 \%(\mathrm{v} / \mathrm{v})$ IsoVitaleX; (ix) semi-solid Lab GCI agar; (x) GCI broth; (xi) MM broth.

After $5 \mathrm{~d}$ incubation, the fluid from each agar culture was extracted as described above and that of the semi-solid agar and broth cultures was extracted by centrifugation at $1800 \mathrm{~g}$ for $20 \mathrm{~min}$ followed by filtration of the supernatant fluid through a $0.45 \mu \mathrm{m}$ membrane (Millipore). The semi-solid agar cultures were also sampled after 7 and $11 \mathrm{~d}$ incubation. The gonococcal inhibitory activity of the samples thus obtained was then determined by plate assay as described above.

Dialysis. The unused portion (approx. 10 to $30 \mathrm{ml}$ ) of supernatant fluid from $E$. coli ' $D$ ' cultures which demonstrated gonococcal inhibitory activity was distributed equally between dialysis tubing retaining substances having the following molecular weights: 12000 (Fisher, Houston, Tex., U.S.A.); 3500 (Spectrum, Los Angeles, Calif., U.S.A.) and 2000 (Spectrum). All samples were dialysed against double-distilled water at a ratio of $50 \mathrm{ml}$ water to $1 \mathrm{ml}$ supernatant fluid at $4{ }^{\circ} \mathrm{C}$ with constant stirring for $3 \mathrm{~d}$, except for those contained within the Spectrum 2000 which were dialysed for an additional $7 \mathrm{~d}$. The water surrounding the dialysis bags was changed daily. Subsequently, the material in each bag was removed. The double-distilled water dialysate was evaporated to dryness at $60^{\circ} \mathrm{C}$ and then reconstituted with $1 \mathrm{ml}$ double-distilled water. After sterilization by filtration through a $0.45 \mu \mathrm{m}$ membrane filter (Millipore) the dialysis residuum and the reconstituted dialysate were either combined in $25 \mu \mathrm{l}$ amounts $(1: 1)$ or kept separate and tested for the presence of gonococcal inhibitory activity by the plate assay.

Ultrafiltration of supernatant fuids. Supernatant fluids extracted from GCI agar plates, either inoculated with $E$. coli ' $\mathrm{D}$ ' or uninoculated (control) as described previously, were ultrafiltered through membranes (Amicon, Lexington, Mass., U.S.A.) with various molecular weight cut-offs: PM10 (10000), DM5 (5000), UM05 (500), UM2 (1000), UM10 (10000) and UM20 (20000). Supernatant fluids were concentrated to approx. 30 to $55 \%$ of their original volume. The filtrates and the supernatant fluid concentrates were then sterilized by filtration through a $0.45 \mu \mathrm{m}$ membrane and assayed by the plate assay.

In addition, an E. coli ' $D$ ' supernatant fluid was concentrated on a PM10 membrane to 90 to $98 \%$ of the original volume and the filtrate was further concentrated on a UM20 membrane to $2 \%$ of its original volume. The residuum was reconstituted with distilled water or $0.067 \mathrm{M}-\mathrm{KH}_{2} \mathrm{PO}_{4} / \mathrm{Na}_{2} \mathrm{HPO}_{4}$ buffer, $\mathrm{pH} 7$, to $50 \%$ of the volume originally placed in the filtration unit. This fluid was the partially purified inhibitor of gonococcal growth produced by $E$. coli (designated PPI $E$. coli). Control supernatant, as described above, was processed in the same manner and termed partially purified control.

Gel filtration. A sample of PPI E. coli was passed through a Sephadex G-25 column $(450 \times 25 \mathrm{~mm})$ and eluted with $0.067 \mathrm{M}-\mathrm{KH}_{2} \mathrm{PO}_{4} / \mathrm{Na}_{2} \mathrm{HPO}_{4}$ buffer, $\mathrm{pH}$ 7. Fractions of $2 \mathrm{ml}$ were collected, their $A_{225}$ values were determined and absorbing and non-absorbing fractions were pooled, dried at $60^{\circ} \mathrm{C}$ and each fraction was reconstituted to one-half the volume of solution placed on the column. These reconstituted pools were then sterilized by filtration through a $0.45 \mu \mathrm{m}$ membrane and examined for inhibition of gonococcal growth by the plate assay.

Ion-exchange chromatography. A $1 \mathrm{ml}$ sample of PPI E. coli was applied to a DEAE-Sephadex A-50 column $(155 \times 10 \mathrm{~mm})$ equilibrated with $0.01 \mathrm{M}-\mathrm{KH}_{2} \mathrm{PO}_{4}$ buffer, $\mathrm{pH} 4.5$, and eluted with a 0.01 to $1 \mathrm{M}-$ $\mathrm{KH}_{2} \mathrm{PO}_{4}$ gradient, $\mathrm{pH} 4 \cdot 5$. As described for gel filtration, $2 \mathrm{ml}$ fractions were collected, their $\boldsymbol{A}_{225}$ values were determined and absorbing and non-absorbing fractions were pooled. Each pool was then concentrated to $<0.5 \mathrm{ml}$ on a UM20 membrane, resuspended in $0.5 \mathrm{ml}$ distilled water, sterilized by filtration through a $0.45 \mu \mathrm{m}$ membrane and assayed for inhibitory activity.

Exposure of PPI E. coli to heat, change of pH, enzymic or chemical treatment. One to five $\mathrm{ml}$ samples of PPI $E$. coli were treated in one of the following ways: (i) heating in stoppered vials to either 80,90 or $100{ }^{\circ} \mathrm{C}$ and in an unstoppered vial to $100^{\circ} \mathrm{C}$; (ii) storage at $4{ }^{\circ} \mathrm{C}$ for 8 weeks or at $0^{\circ} \mathrm{C}$ for 1 week; (iii) adjustment to pH 1.5 with $1 \mathrm{M}-\mathrm{HCl}$ followed by incubation at $37^{\circ} \mathrm{C}$ for $1 \mathrm{~h}$; (iv) adjustment to $\mathrm{pH} 1.5$ with $1 \mathrm{M}-\mathrm{HCl}$, incubation at $37^{\circ} \mathrm{C}$ for $1 \mathrm{~h}$, readjustment with $1 \mathrm{M}-\mathrm{NaOH}$ to $\mathrm{pH} 12 \cdot 3$ followed by incubation at $37^{\circ} \mathrm{C}$ for $1 \mathrm{~h}$. (v) adjustment to $\mathrm{pH}<2$ with $1 \mathrm{M}-\mathrm{HCl}$, addition of pepsin (Sigma) at $1 \mathrm{mg} \mathrm{ml}^{-1}$, incubation at $37^{\circ} \mathrm{C}$ for $1 \mathrm{~h}$, adjustment to $\mathrm{pH}>11$ with $1 \mathrm{M}-\mathrm{NaOH}$ to activate the pepsin and final readjustment to $\mathrm{pH} 7$ with $1 \mathrm{M}-\mathrm{HCl}$; (vi) addition of trypsin (ICN, Cleveland, Ohio, U.S.A.) at $0.01 \mathrm{~g} \mathrm{ml}^{-1}$, incubation at $37^{\circ} \mathrm{C}$ for $1 \mathrm{~h}$, addition of soybean trypsin inhibitor ( $5 \times$ crystallized; Nutritional Biochemical Corp., Cleveland, Ohio, U.S.A.) at $0.005 \mathrm{~g} \mathrm{ml}^{-1}$ and incubation at $37^{\circ} \mathrm{C}$ for a further $1 \mathrm{~h}$ to inactivate the trypsin; (vii) addition of either RNAase $(5 \times$ crystallized; Nutritional Biochemical Corp.) or DNAase II (Worthington, Freehold, N.J., U.S.A.) at $0.005 \mathrm{~g} \mathrm{ml}^{-1}$, incubation at $37^{\circ} \mathrm{C}$ for $1 \mathrm{~h}$ followed by heating at $70^{\circ} \mathrm{C}$ for $30 \mathrm{~min}$ to inactivate the nucleases; (viii) addition of either lipase Type VI (Sigma) or lysozyme ( $3 \times$ crystallized; Sigma) at $0.001 \mathrm{~g}$ $\mathrm{ml}^{-1}$, incubation at $37^{\circ} \mathrm{C}$ for $1 \mathrm{~h}$ followed by heating at $80^{\circ} \mathrm{C}$ for 30 min to inactivate the enzymes; (ix) incubation at $37^{\circ} \mathrm{C}$ for $1 \mathrm{~h}$ with either $0.02 \mathrm{M}$-sodium citrate (Fisher, Houston, Tex., U.S.A.), $0.2 \mathrm{M}$-EDTA 
Table 1. Growth of N. gonorrhoeae in GCI broth (2 parts) and supernatant fluid from E. coli ' $D$ ' plate cultures (1 part)

\begin{tabular}{|c|c|c|c|c|c|c|}
\hline \multirow[b]{3}{*}{ Expt no. $\uparrow$} & \multicolumn{6}{|c|}{ Average* no. of c.f.u. $(10 \mu \mathrm{l})^{-1}$ at indicated times } \\
\hline & \multicolumn{3}{|c|}{ E. coli 'D' supernatant fluid } & \multicolumn{3}{|c|}{ Control supernatant fluid } \\
\hline & $10 \mathrm{~min}$ & $4 \mathrm{~h}$ & $8 \mathrm{~h}$ & $10 \mathrm{~min}$ & $4 \mathrm{~h}$ & $8 \mathrm{~h}$ \\
\hline 1 & $\begin{array}{r}10 \\
8\end{array}$ & $\begin{array}{r}5 \\
14\end{array}$ & $\begin{array}{r}16 \\
6\end{array}$ & $\begin{array}{r}8 \\
12\end{array}$ & $\begin{array}{l}19 \\
13\end{array}$ & $\begin{array}{r}155 \\
96\end{array}$ \\
\hline 2 & 7 & 17 & 84 & 6 & 2 & 147 \\
\hline 3 & 3 & 0.3 & $\mathbf{0}$ & 3 & $\overline{8}$ & 152 \\
\hline 4 & 3 & $0 \cdot 3$ & 0 & 1 & 3 & 33 \\
\hline 5 & 2 & 4 & 11 & 3 & 8 & 63 \\
\hline 6 & 2 & 11 & 7 & 5 & 20 & 157 \\
\hline
\end{tabular}

* Average of two or three samples.

$\uparrow$ Indicates individual preparations of $E$. coli ' $D$ ' supernatant fluid.

(Nutritional Biochemical Corp.), 2\% (w/v) bovine serum albumin (BSA) Fraction V (Nutritional Biochemical Corp.), $1 \%(\mathrm{w} / \mathrm{v})$ soluble starch (Difco), $1 \%(\mathrm{w} / \mathrm{v}) \mathrm{MgCl}_{2} \cdot 6 \mathrm{H}_{2} \mathrm{O}$ (Baker Chemical, Phillipsburg. Penn., U.S.A.), $1 \%$ (w/v) $\mathrm{CaCl}_{2} .2 \mathrm{H}_{2} \mathrm{O}$ (Fisher) or $1 \%(\mathrm{w} / \mathrm{v}$ ) ferric ammonium citrate (Baker Chemical). Appropriate control samples were prepared and tested in parallel with each treated PPI E. coli sample. All samples, both treated and control, were sterilized by filtration through a $0.45 \mu \mathrm{m}$ membrane (Millipore) prior to assay for inhibition of gonococcal growth.

\section{RESULTS}

\section{Extent of gonococcal inhibition by $E$. coli ' $D$ '}

Samples taken in the late growth phase of $E$. coli ' D' produced wider zones of inhibition against $N$. gonorrhoeae than samples taken earlier. The average width of the zone of inhibition was $0,2 \cdot 0,6 \cdot 0,9 \cdot 8,15 \cdot 5,18.0$ and $23.5 \mathrm{~mm}$ at 7.5 and $15.5 \mathrm{~h}, 1,2,3,4$ and $5 \mathrm{~d}$, respectively. In contrast, the inhibition produced by $E$. coli ' $B$ ' after growth for $1 \mathrm{~d}$ was limited almost completely to the area underneath its growth. Escherichia coli 'B' growth older than $1 \mathrm{~d}$ led to an inconsistent pattern of inhibition with large patches of gonococcal cells arising over the original area of growth. No such patches of gonococci were observed with E. coli ' $\mathrm{D}$ '.

All seven strains of $N$. gonorrhoeae tested were inhibited by the $E$. coli ' D' culture, as were all four colony types of F62.

Growth of the three $N$. gonorrhoeae strains examined (F62, Catlins auxotype 1 and a clinical isolate) was still inhibited on plates which had been resupplied, after $E$. coli ' $\mathrm{D}$ ' growth and removal but before gonococcal challenge, with polypeptone peptone and IsoVitaleX.

When cell-free inhibitor extracted from $E$. coli ' D' plate cultures was added to GCI broth, multiplication of the standard inoculum of $N$. gonorrhoeae F62 colony type 4 was prevented over an $8 \mathrm{~h}$ period in 6 out of 7 experiments. Over the same period, the standard inoculum in the controls increased at least 20 -fold in 6 out of 7 experiments (Table 1).

\section{Influence of composition of medium on production of gonococcal inhibitor by $E$. coli ' $D$ '}

In general the gonococcal inhibitor was produced only when $E$. coli ' $\mathrm{D}$ ' was grown on an agar medium. The only essential component of the medium was peptone, although not all peptones were equally effective (Table 2). Peptone at $10 \mathrm{~g} \mathrm{l}^{-1}$ or more led to maximum production of the gonococcal inhibitor. However, increasing IsoVitaleX to $5 \%(\mathrm{v} / \mathrm{v})$ decreased the amount of gonococcal inhibitor produced (Table 2). 
Table 2. Influence of medium composition on gonococcal inhibitor production by E. coli ' $D$ '

Medium on which $E$. coli 'D' was grown

(i) GCI agar: GC Agar base (BBL)

GC Medium base (Difco) Lot No. 637166

GC Medium base (Difco) Lot No. 634368

Lab GCI agar

(ii) Lab GCI agar without: Polypeptone peptone

$\mathrm{NaCl}$, or starch, or IsoVitaleX or nothing

(iii) Polypeptone peptone/Bacto-agar

(iv) Polypeptone peptone/purified agar

(v) Bacto-peptone/purified agar

(vi) Lab GCI agar containing polypeptone peptone: $5 \mathrm{~g} \mathrm{I}^{-1}$

(vii) Lab GCI agar containing Bacto-peptone $\left(15 \mathrm{~g}^{-1}\right)$

(viii) Lab GCI agar containing $5 \%$ (v/v) IsoVitaleX

(ix) Semi-solid Lab GCI agar (11 d incubation)

(x) GCI broth

(xi) MM broth

$\begin{array}{cc}\begin{array}{c}\text { Average zone of } \\ \text { Width } \\ (\mathrm{mm})\end{array} & \text { Grade* } \\ 6 \cdot 6 & 2+-3+ \\ 3 \cdot 3 & 1+-2+ \\ 7 \cdot 5 & 3+ \\ 9 \cdot 5 & 3+ \\ \text { None } & 0 \\ 9 \cdot 0-10 \cdot 0 & 3+ \\ 7 \cdot 0 & 3+ \\ 9 \cdot 0 & 3+ \\ \text { None } & 0 \\ 3 \cdot 0 & 1+ \\ 7 \cdot 5-8 \cdot 6 & 3+ \\ 6 \cdot 0 & 3+ \\ 4 \cdot 5 & 3+ \\ 4 \cdot 0 & 1+ \\ \text { None } & 0 \\ \text { None } & 0\end{array}$

$* 3+$, Clear zone around well bordered by a narrower zone of small colonies; $2+$, clear zone around well bordered by a larger zone of small colonies; $1+$, zone of small colonies around well; 0 , no inhibition evident.

\section{Dialysis and ultrafiltration}

The inhibitor present in $E$. coli ' D' supernatant fluid permeated all dialysis tubing tested, except that tubing retaining substances having a molecular weight $>2000$ required more daily changes of water and a longer time $(10 \mathrm{~d}$ instead of $3 \mathrm{~d})$ for diffusion of the inhibitor to be completed.

Of the ultrafiltration membranes tested, only PM10 was consistently permeable to the inhibitor present in $E$. coli ' D' supernatant fluid although, on occasion, DM20 did allow the inhibitor through. The inhibitor was concentrated in the residuum following ultrafiltration through DM and UM membranes and this gave an increase in the width of the inhibition zones from approx. $7 \cdot 5$ to approx. $12.5 \mathrm{~mm}$ with the character of the inhibition remaining the same, i.e. $3+$.

\section{Sephadex G-25 gel filtration and DEAE-Sephadex A-50 ion-exchange chromatography}

PPI $E$. coli chromatographed on Sephadex G-25 and eluted with phosphate buffer, pH 7, produced a larger second absorbance peak than when eluted with distilled water (Fig. 1). The inhibitory activity of the sample eluted with phosphate buffer was in the second peak while that of the sample eluted with water was in the first peak. The inhibitory activity of both samples eluted from the columns in the region where the marker bacitracin (approx. mol. wt 1450) eluted, while another marker, penicillin (approx. mol. wt 375), eluted in the area of fraction 110 .

PPI $E$. coli showed two peaks of absorbance after DEAE-Sephadex A-50 ion-exchange chromatography against a 0.01 to $1 \mathrm{M}$-phosphate buffer gradient, $\mathrm{pH} 4.5$ (Fig. 2). The plate assay showed that inhibitory activity was present only in the second pool which contained the second peak.

\section{Stability of PPI E. coli after heat, enzymic or chemical treatment}

PPI $E$. coli proved to be very resistant to most treatments (see Methods). However, heating at $100^{\circ} \mathrm{C}$ for $1 \mathrm{~h}$ in either stoppered or unstoppered vials reduced the inhibition zone by $2 \mathrm{~mm}$ and treatment with ferric ammonium citrate eliminated it completely. 

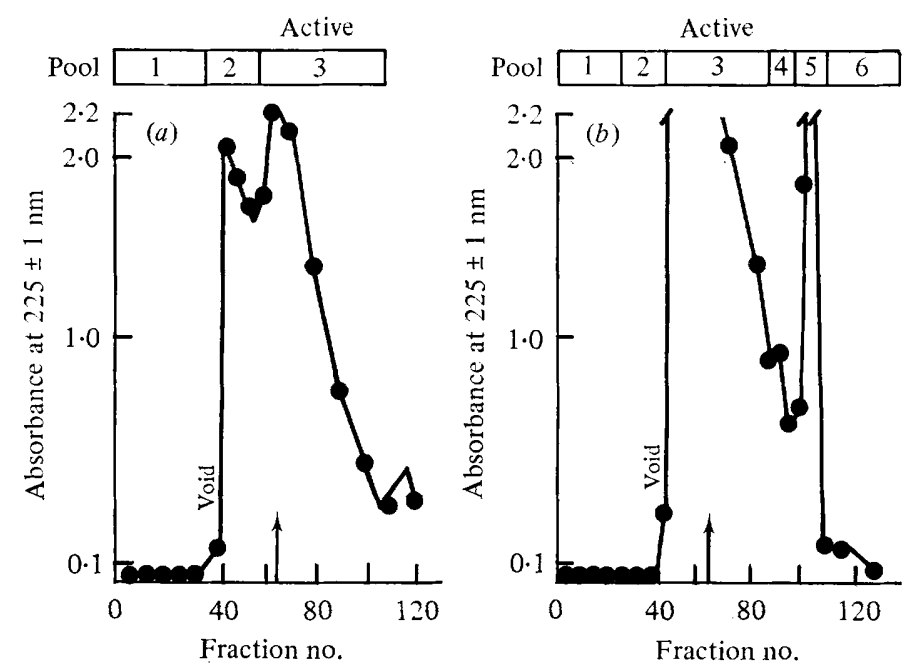

Fig. 1. PPI $E$. coli elution patterns on a Sephadex G-25 column: (a) 0.067 $\mathrm{M}-\mathrm{KH}_{2} \mathrm{PO}_{4} / \mathrm{Na}_{2} \mathrm{HPO}_{4}$ buffer, $\mathrm{pH} 7 ;(b)$ double-distilled water. Arrows indicate where bacitracin (mol. wt 1450) was eluted while 'active' indicates the eluate pool which gave zones in the plate assay.

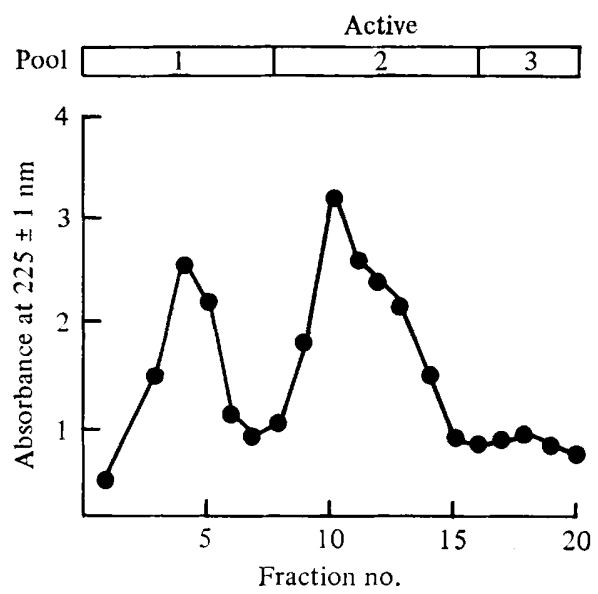

Fig. 2. PPI E. coli elution pattern on a DEAE-Sephadex A-50 column eluted with a $\mathrm{KH}_{2} \mathrm{PO}_{4}$ buffer gradient of $0.01 \mathrm{M}$ to $1 \mathrm{M}, \mathrm{pH} 4.5$. 'Active' indicates the eluate pool which gave zones in the plate assay.

\section{DISCUSSION}

In surveys conducted by Geizer (1968), Kraus et al. (1976) and Kaye \& Levison (1977) on the various bacteria capable of inhibiting the growth of $N$. gonorrhoeae in vitro, no investigations into the mechanisms by which growth was inhibited were reported. This report contains the first analysis of the medium components needed for the production of a cell-free gonococcal growth inhibitor produced by an $E$. coli ' $D$ ' strain.

Kraus et al. (1976) made the initial observation on differences in the ability of $E$. coli strains to inhibit $N$. gonorrhoeae. That differences do exist has been confirmed by the findings reported here with the strains of $E$. coli ' $\mathrm{B}$ ' and ' $\mathrm{D}$ ' isolated by us. Kraus et al. (1976) based their classification on the ability of strains to inhibit light or heavy challenges of $N$. gonorrhoeae and on the extent of the inhibition produced. However, the results reported here for $E$. coli 'B', where a $1 \mathrm{~d}$-old colony produced a small zone of inhibition and an older one produced either no defined zone or patchy areas of inhibition, suggest that the age of the 
$E$. coli colony at the time of challenge should also be considered in drawing up a classification.

This is the first report of gonococcal inhibition in assay systems (plate and broth) free of $E$. coli whole cells. Use of these systems revealed that $E$. coli ' $\mathrm{D}$ ' produced a substance that inhibited gonococcal growth and was not merely depleting the medium of nutrients essential to the growth of $N$. gonorrhoeae. Furthermore, the results suggested that at the concentrations of the inhibitor used, the inhibitor was bacteriostatic and not bactericidal since in the samples removed from the broth assay, the number of c.f.u. of $N$. gonorrhoeae recovered were often approximately the same as in the initial inoculum. In addition, subculture from zones of inhibition present on assay plates, where no gonococcal colonies were visible, led to the recovery of $N$. gonorrhoeae.

The ability of $E$. coli ' $\mathrm{D}$ ' to inhibit all the strains and colony types of $N$. gonorrhoeae tested indicated that the inhibitor was not specific for gonococcal pili or some other characteristic associated with a particular colony type or strain. The inhibition of a $\beta$-lactamase producing gonococcal strain suggests the inhibitor is not a $\beta$-lactamase sensitive structure.

Ultrafiltration and column chromatography indicated that the inhibitor had a molecular weight of 1200 to 2000 . The behaviour of the molecule on Amicon UM membranes, which contain sites of ionic charge, and its elution pattern on DEAE-Sephadex A-50 suggest that the molecule contains ionizable groups. Characterization of the molecule to date has been only partially successful. Partially purified inhibitor was relatively stable to heat, $\mathrm{pH}$ and cold storage. None of the enzymes tested destroyed its gonococcal inhibitory activity nor did chelating agents or substances that bind lipids. In addition, ultraviolet absorption spectra of the substance showed no absorption peak at 260 or $280 \mathrm{~nm}$. The gonococcal inhibitor is therefore distinct from previously reported inhibitors of bacterial origin (Morse et al., 1976; Walstadt et al., 1974; Hsu \& Wiseman, 1967).

The availability of iron has been shown to influence the virulence of $N$.gonorrhoeae (Payne \& Finkelstein, 1975). Hafiz et al. (1977) demonstrated that iron can cause $N$. gonorrhoeae to revert to virulent colony types in vitro. Competition for iron between $E$. coli, $N$. gonorrhoeae and host cells could influence the onset and perhaps the outcome of gonorrhoea. Consequently, if the gonococcal inhibitor, which apparently binds iron, is produced by E. coli in vivo, it may play an important role in inhibiting gonococcal growth.

We wish to thank Duc Si Dong for his technical help. This work was supported in part by grants RR05427, AM14945 and AI14508. D. M.S. was supported by a predoctoral fellowship from the James W. McLaughlin Fellowship Fund.

\section{REFERENCES}

GeIzer, E. (1968). Antibacterial substances produced from different bacteria inhibiting the growth of Neisseria gonorrhoeae. Journal of Hygiene, Epidemiology, Microbiology, Immunology 12, 241-243.

Hafiz, S., McEntegart, M. G. \& Jephcott, A. E. (1977). Reversion of Kellogg's colonial types of Neisseria gonorrhoeae in liquid medium. Journal of Medical Microbiology 10, 377-380.

Hsu, C. Y. \& Wiseman, G. M. (1967). Antibacterial substances from staphylococci. Canadian Journal of Microbiology 13, 947-955.

KAYE, D. \& Levison, M. (1977). In vitro inhibition of growth of Neisseria gonorrhoeae by genital microorganisms. Sexually Transmitted Diseases 4, 1-3.

Kekessy, D. A. \& Piquet, J. D. (1970). New method for detecting bacteriocin production. Applied Microbiology 27, 192-196.
Kraus, S. J., Geller, R. C., Perkins, G. H. \& RHODEN, D. C. (1976). Interference of Neisseria gonorrhoeae growth by other bacterial species. Journal of Clinical Microbiology 4, 288-295.

Morse, S. A., Vaughn, P., Johnson, D. \& IGelwSKI, B. H. (1976). Inhibition of Neisseria gonorrhoeae by a bacteriocin from Pseudomonas aeruginosa. Antimicrobial Agents and Chemotherapy 10, 417-420.

Payne, S. M. \& Finkelstein, R. A. (1975). Pathogenesis and immunology of experimental gonococcal infection: role of iron in virulence. Infection and Immunity 12, 1313-1318.

Walstadt, D. L., Reitz, R. C. \& Sparling, P. F. (1974). Growth inhibition among strains of Neisseria gonorrhoeae due to production of inhibitory free fatty acids and lysophosphatidylethanolamine: absence of bacteriocins. Infection and Immunity 10, 481-488. 